IJMS 17 (2), 253-274 (2010)

\title{
INDEKS MODAL SOSIAL DAN AGIHAN PENDAPATAN DI MALAYSIA
}

\author{
MOHD. NASIR MOHD. SAUKANI \\ RAHMAH ISMAIL \\ ISHAK YUSSOF \\ Fakulti Ekonomi dan Perniagaan \\ Universiti Kebangsaan Malaysia
}

\begin{abstract}
Abstrak
Makalah ini bertujuan untuk melihat pengaruh modal sosial terhadap agihan pendapatan isi rumah antara wilayah di Malaysia. Modal yang bersifat subjektif dan "intangible" ini dirujuk sebagai "relational embeddedness" yang akan memudahkan kerjasama dilakukan di antara individu atau kumpulan untuk mencapai matlamat tertentu. Pencapaian matlamat ini akan berlaku melalui kombinasi ciri modal sosial, iaitu kepercayaan, jaringan/hubungan dan norma hidup individu atau kumpulan. Analisis dalam makalah ini adalah berdasarkan kepada 4003 isi rumah yang telah ditemu bual pada 2007/2008 di seluruh Semenanjung Malaysia. Melalui pembentukan model dengan menggunakan peratus pendapatan setiap isi rumah sebagai pengukur agihan pendapatan, pengaruh modal sosial terhadap agihan pendapatan isi rumah akan dianalisis menggunakan indeks modal sosial yang telah dibangunkan. Pemboleh ubah modal manusia seperti tahap pendidikan, latihan, pengalaman kerja dan kesihatan serta demografi dan wilayah juga diambil kira dalam penganggaran model ini. Kajian ini mendapati modal sosial memberi impak yang positif terhadap agihan pendapatan walaupun pengaruhnya lebih kecil berbanding pengaruh modal manusia.
\end{abstract}

Kata kunci: Modal sosial; modal manusia; indeks modal sosial; indeks modal manusia; agihan pendapatan.

\begin{abstract}
The objective of this paper is to analyse the influence of social capital on household income distribution. Advocates of this subjective and intagible capital have recognised it as "relational embeddedness" that facilitates cooperation between individuals or groups to achieve certain objectives.
\end{abstract}


Achieving the objectives of that particular relation will be furnished by the combination of trust, networks, and norms, i.e. elements of social capital. The analysis was based on data collected from a field survey on 4003 households conducted in Peninsular Malaysia in 2007/2008. Using the specified model with household income percentage as the measurement of income distribution and by forming the social capital index, this study estimated the influence of social capital variables, such as good relationship among family members, neighbours, and friends; involvement in association; and good norms on income distribution. Human capital variables such as the level of education, training and healthcare, and demografics was also included in this estimation. We hypothesised that social capital variables will generate a positive impact on household income distribution although its influence is lower compared to human capital.

Keywords: Social capital; human capital; social capital index; human capital index; income distribution.

\section{Pengenalan}

Walaupun diakui taraf hidup hampir keseluruhan rakyat Malaysia telah meningkat, ketidaksamaan pendapatan yang berlaku terutama antara etnik, wilayah dan negeri kekal menjadi isu yang tiada penyelesaian konkrit hingga kini. Rancangan Malaysia Ke-Sembilan (RMK-9) memperlihatkan insiden ketidaksamaan agihan pendapatan antara negeri dan wilayah yang berterusan dan semakin melebar. Jurang ketidaksamaan pendapatan antara etnik dari segi nilai mutlak juga terus melebar walaupun berjaya mencatatkan penurunan dari segi nilai relatif (Malaysia, 2006). Usaha berterusan dan konkrit pihak kerajaan dalam meningkatkan pertumbuhan dan pembangunan ekonomi negara seterusnya memperbaiki kualiti hidup penduduk diakui tidak sepenuhnya berjaya dalam mengimbangi peratus jumlah kekayaan negara yang sepatutnya dinikmati oleh setiap kelompok masyarakat.

Teori modal manusia menjelaskan bahawa wujud hubungan positif antara pencapaian modal manusia dengan tingkat pendapatan yang akan diterima oleh seseorang individu. Pelaburan terhadap modal manusia (dalam bentuk pendidikan, latihan dan kesihatan) akan memberi kesan yang positif kepada pulangan pendapatan individu/isi rumah. Selain modal manusia, kajian ekonomi kini semakin memberi fokus terhadap kepentingan faktor hubungan (relationships) di antara individu dengan individu lain (komponen modal sosial) yang penting kepada pertumbuhan ekonomi. Modal yang bersifat subjektif dan 
"intangible" ini diiktiraf oleh para pendokongnya sebagai "relational embeddedness" yang akan memudahkan kerjasama dilakukan di antara individu atau kumpulan untuk mencapai matlamat tertentu. Menurut Robinson (1999), pengagihan pendapatan sebahagian besarnya bergantung kepada terms of trade untuk pertukaran perkhidmatan atau barangan yang dilakukan oleh individu. Faktor hubungan pula merupakan salah satu komponen penting modal sosial dan amat mempengaruhi terms of trade, maka secara tidak langsung akan mempengaruhi pendapatan dan agihan pendapatan.

Makalah ini akan menganalisis pengaruh modal sosial terhadap agihan pendapatan isi rumah antara wilayah di Malaysia. Analisis dalam kajian ini adalah berdasarkan kepada 4003 ketua isi rumah yang telah ditemubual pada 2007/2008 di seluruh Semenanjung Malaysia. Pemboleh ubah modal sosial seperti hubungan baik sesama keluarga, jiran dan rakan; penyertaan dalam persatuan dan norma hidup yang baik akan dianalisiskan pengaruhnya terhadap agihan pendapatan melalui pembentukan indeks modal sosial. Dengan menggunakan peratus pendapatan setiap isi rumah sebagai pengukur agihan pendapatan, pengaruh pemboleh ubah lain seperti tahap pendidikan, latihan, pengalaman bekerja dan kesihatan serta demografi terhadap agihan pendapatan isi rumah juga akan dianalisis dalam kajian ini.

\section{Definisi Modal Sosial}

Kecenderungan ahli-ahli ekonomi untuk mengkaji mengenai modal sosial bermula dari kajian Coleman (ahli sosiologi) pada tahun 1988 dan Putnam (ahli sains politik) pada tahun 1993. Kedua-dua kajian penting ini telah mencambahkan minat pengkaji daripada bidang lain seperti ekonomi untuk meneroka kepentingan aspek hubungan sosial manusia ini. Terdapat pelbagai definisi yang diberikan oleh para pengkaji dan adalah sukar untuk menetapkan satu definisi yang standard bagi modal sosial (lihat Jadual 1). Namun demikian, umumnya kebanyakan definisi yang dikemukakan mengambil kira elemen kepercayaan, rangkaian dan keahlian dalam persatuan serta norma hidup yang dikongsi bersama sebagai indikator-indikator untuk mengukur modal sosial.

Berdasarkan Jadual 1, definisi yang paling banyak digunakan oleh para pengkaji adalah berdasarkan idea Putnam et al. (1993) yang menekankan kepada aspek kepercayaan, norma dan rangkaian. Idea Putnam (terutamanya norma dan rangkaian) telah digunakan dalam kebanyakan definisi yang diberikan oleh para pengkaji. Definisi yang 
diberikan oleh Durlauf dan Fafchamps (2004) pula dianggap sebagai antara yang terbaik bagi menerangkan modal sosial. Walaupun setiap pengkaji mempunyai takrifan tersendiri bagi menerangkan modal sosial, sebahagian besar daripada mereka tidak menolak definisi yang mengambil kira elemen kepercayaan, rangkaian (keanggotaan dalam persatuan) dan norma hidup (Knowles, 2005). Justeru, pendefinisian modal sosial wajar mengguna pakai idea yang diterima oleh kebanyakan pengkaji walaupun sehingga kini masih belum ada persetujuan bersama berhubung standard definisi yang perlu diguna pakai.

Dalam erti kata lain, modal sosial merujuk kepada tingkat kepercayaan, komunikasi, hubungan, kerjasama dan norma hidup baik yang dipupuk, dibentuk, dikekal dan dikongsi oleh sekurangkurangnya dua orang individu atau firma. Hubungan yang dijalin dan dipupuk atas dasar kepercayaan dan nilai baik akan mewujudkan ruang kepada perkongsian maklumat dan pembentukan rangkaian yang akan menghasilkan manafaat kepada individu/firma yang terlibat. Modal sosial memerlukan masa dan tenaga untuk dibangun, dikekal dan ditingkatkan. Kebolehupayaan seseorang individu atau firma untuk berjaya dan survive pada masa kini bukan hanya bergantung kepada faktor pemilikan modal fizikal (aset kewangan dan aset fizikal) dan modal manusia (tingkat pendidikan dan kemahiran) tetapi turut ditentukan oleh faktor hubungan sosial sesama manusia yang semakin diiktiraf sebagai modal keempat kepada pertumbuhan ekonomi (Piazza-Georgi 2002; Woolcock et al., 2000; Woolcock, 1998).

Jadual 1

Definisi Modal Sosial

\begin{tabular}{ll}
\hline Penulis/Pengkaji & \multicolumn{1}{c}{ Definisi } \\
\hline Coleman (1988, m/s:95) & $\begin{array}{l}\text { "jangkaan dan pematuhan, saluran-saluran } \\
\text { informasi dan norma sosial" }\end{array}$ \\
$\begin{array}{l}\text { Coleman (1990, } \\
\text { m/s;304) }\end{array}$ & $\begin{array}{l}\text { "organisasi sosial yang akan membantu pencapaian } \\
\text { matlamat-matlamat yang tidak mungkin dicapai } \\
\text { tanpanya atau mungkin boleh dicapai tetapi } \\
\text { melibatkan kos yang lebih tinggi" }\end{array}$ \\
$\begin{array}{l}\text { Putnam et al. (1993, } \\
\text { m/s;167) }\end{array}$ & $\begin{array}{l}\text { "ciri-ciri organisasi sosial seperti kepercayaan, } \\
\text { merma-norma dan rangkaian yang akan }\end{array}$ \\
\hline
\end{tabular}

(sambungan) 


\begin{tabular}{|c|c|}
\hline Penulis/Pengkaji & Definisi \\
\hline $\begin{array}{l}\text { Fukuyama (1997, } \\
\mathrm{m} / \mathrm{s}: 378-379)\end{array}$ & $\begin{array}{l}\text { "...set peraturan atau norma tidak formal } \\
\text { tertentu yang dikongsi di antara ahli-ahli sesuatu } \\
\text { kumpulan yang akan membenarkan kerjasama } \\
\text { berlaku antara mereka. Perkongsian nilai dan } \\
\text { norma tidak semestinya menghasilkan modal } \\
\text { sosial ...norma yang menghasilkan modal } \\
\text { sosial mesti mengandungi ciri seperti berkata } \\
\text { benar, menunaikan tanggungjawab dan saling } \\
\text { bekerjasama" }\end{array}$ \\
\hline $\begin{array}{l}\text { Knack dan Keefer } \\
(1997, \mathrm{~m} / \mathrm{s} ; 1251)\end{array}$ & $\begin{array}{l}\text { "kepercayaan, norma kerjasama dan persatuan di } \\
\text { dalam kumpulan" }\end{array}$ \\
\hline $\begin{array}{l}\text { Narayan dan Pritchett } \\
(1999, \mathrm{~m} / \mathrm{s}: 872)\end{array}$ & $\begin{array}{l}\text { "kuantiti dan kualiti hubungan manusia dengan } \\
\text { persatuan dan norma sosial lain yang berkaitan" }\end{array}$ \\
\hline Putnam (2000, m/s;19) & $\begin{array}{l}\text { "hubungan antara individu - rangkaian sosial dan } \\
\text { norma kerjasama dan kepercayaan yang wujud } \\
\text { dari hubungan tersebut" }\end{array}$ \\
\hline Ostrom (2000, m/s:176) & $\begin{array}{l}\text { "pengetahuan, pemahaman, norma, peraturan dan } \\
\text { jangkaan yang dikongsi mengenai amalan corak } \\
\text { perhubungan sesuatu kumpulan, }\end{array}$ \\
\hline $\begin{array}{l}\text { Woolcock dan Narayan } \\
(2000, \mathrm{~m} / \mathrm{s}: 225)\end{array}$ & $\begin{array}{l}\text { "norma dan rangkaian yang membolehkan } \\
\text { manusia untuk bertindak secara kolektif" }\end{array}$ \\
\hline $\begin{array}{l}\text { Bowles dan Gintis } \\
(2002, \mathrm{~m} / \mathrm{s}: 2)\end{array}$ & $\begin{array}{l}\text { "kepercayaan, perhatian ...kesanggupan untuk } \\
\text { hidup berdasarkan norma masyarakat dan untuk } \\
\text { menghukum mereka yang tidak mematuhinya" }\end{array}$ \\
\hline Lin (2001, m/s:24-25) & $\begin{array}{l}\text { "sumber-sumber terkandung dalam rangkaian } \\
\text { sosial...terdiri dari dua komponen penting } \\
\text { iaitu (1) ianya mewakili sumber-sumber yang } \\
\text { terkandung dalam hubungan sosial dan (2) akses } \\
\text { dan pengggunaan sumber tersebut terkandung } \\
\text { dalam diri individu-individu terbabit" }\end{array}$ \\
\hline Knack (2002, m/s:42) & $\begin{array}{l}\text { "modal sosial umum meliputi nilai, norma, } \\
\text { rangkaian tidak formal dan keanggotaan dalam } \\
\text { persatuan yang akan memberi kesan kepada } \\
\text { keupayaaan individu untuk bekerja bagi mencapai } \\
\text { matlamat umum" }\end{array}$ \\
\hline Sobel (2002, m/s:139) & $\begin{array}{l}\text { "...situasi dimana individu boleh menggunakan } \\
\text { keanggotaan dalam persatuan dan rangkaian } \\
\text { untuk memperoleh manafaat" }\end{array}$ \\
\hline
\end{tabular}

(sambungan) 


\begin{tabular}{ll}
\hline Penulis/Pengkaji & \multicolumn{1}{c}{ Definisi } \\
\hline Durlauf dan Fafchamps & "(1) modal sosial menghasilkan eksternaliti \\
$(2004, \mathrm{~m} / \mathrm{s}: 5)$ & positif kepada individu yang menyertai sesuatu \\
& persatuan, (2) eksternaliti ini dicapai melalui \\
& perkongsian kepercayaan, norma dan nilai dan \\
& kesannya terhadap jangkaan dan tingkah laku \\
& anggota (3) kepercayaan, norma dan jangkaan \\
& yang dikongsi ini dibentuk dari organisasi tidak \\
& formal berasaskan rangkaian sosial dan persatuan" \\
& "norma dan rangkaian yang membolehkan \\
Bank Dunia (2005) & tindakan secara kolektif dilakukan" \\
\hline
\end{tabular}

Sumber. Knowles, S. (2005).

\section{Kajian Literatur}

Terdapat beberapa kajian emperikal yang telah menganalisis hubungan modal sosial dengan agihan pendapatan. Kajian Knack (2002) menunjukkan kejayaan kerajaan dalam meningkatkan modal sosial, iaitu menerusi amalan pentadbiran yang baik dan mendapat kepercayaan rakyat selain menyumbang kepada peningkatan prestasi ekonomi turut mendatangkan kesan progresif dalam meningkatkan akses penduduk (terutama golongan miskin) terhadap peluang ekonomi, memperbaiki agihan pendapatan dan mengurangkan kadar kemiskinan. Robinson (1999) mendapati peningkatan (penurunan) dalam hubungan sosial di antara individu dan kumpulan akan membantu dalam meningkatkan (mengurangkan) tingkat pendapatan dan mengurangkan (meningkatkan) perbezaan pendapatan isi rumah. Menurut Maluccio et al. (1999), modal sosial dan pendidikan memberikan pulangan yang signifikan kepada pendapatan isi rumah. Penyertaan isi rumah Afrika Selatan di dalam kumpulan/pertubuhan formal dan tidak formal (berkaitan kewangan/tabungan dan aktiviti sosial lain) didapati signifikan dalam meningkatkan pendapatan mereka walaupun kesannya lebih kecil berbanding kesan pencapaian pendidikan. Peningkatan satu peratus dalam indeks modal sosial isi rumah atau masyarakat akan diikuti dengan peningkatan sebanyak $1.2 \%$ dalam perbelanjaan per kapita isi rumah. Secara perbandingan, peningkatan yang sama dalam tingkat pendidikan purata isi rumah memberikan kesan empat kali lebih besar kepada perbelanjaan perkapita. Dapatan kajian Maluccio et al. (1999) telah disokong oleh penemuan kajian Grootaert (1999) yang antara lain mendapati isi rumah yang terlibat secara aktif dalam aktiviti persatuan sama ada sebagai ahli atau terlibat dalam proses membuat keputusan adalah lebih berkemampuan untuk meningkatkan pemilikan aset fizikal 
dan tabungan seterusnya memperbaiki tingkat pendapatan dan taraf kehidupan mereka.

Grootaert dan Narayana (2001) mendapati modal sosial mengurangkan kebarangkalian insiden kemiskinan dalam kalangan penduduk di Bolivia. Menurut kajian ini, pulangan kepada pelaburan dalam modal sosial umumnya lebih besar dalam kalangan isi rumah miskin berbanding isi rumah kaya dan dalam kalangan isi rumah dengan saiz pemilikan tanah yang sedikit berbanding isi rumah yang memiliki tanah yang banyak. Kajian Uchimura (2005) menunjukkan langkah kerajaan China memperkenalkan sistem sekuriti sosial (insurans pencen) telah berjaya memperbaiki ketidakseimbangan agihan pendapatan dalam kalangan pekerja di bandar-bandar besar. Namun demikian, penyertaan atau akses ke dalam sistem sekuriti ini yang dikhususkan kepada pekerja di bandar telah menafikan hak pekerja di kawasan luar bandar serta turut menyumbang kepada ketidakseimbangan agihan pendapatan yang semakin melebar di kawasan luar bandar.

Kajian emperikal juga menunjukkan modal sosial menyumbang kepada peningkatan produktiviti firma. Pengusaha yang menjalin hubungan baik dengan pengusaha dan syarikat lain secara signifikan berupaya memperoleh nilai jualan yang lebih besar berbanding pengusaha yang tidak menjalin sebarang hubungan (Fafchamps \& Minten, 2002). Hubungan perniagaan berasaskan kepercayaan juga berupaya meningkatkan kecekapan firma terutama dari segi memudah dan mengurangkan kos urus niaga. Kepercayaan yang diperoleh akan memanafaatkan firma antaranya dari segi syarat dan fleksibiliti untuk kontrak, kaedah pembayaran, serta kredit dan jaminan perniagaan (Fafchamps \& Minten, 2002; 2001; Bigsten et al. 2000). Firma yang memiliki tingkat modal sosial yang tinggi selalunya turut memiliki kumpulan pengurusan dan pekerja yang memberi fokus kepada kerjasama dalam meningkatkan hasil dan prestasi syarikat. Syarikat yang beroperasi tanpa elemen modal sosial, iaitu kepercayaan, hubungan dan norma baik adalah tidak berkemampuan untuk mengerakkan modal manusia dan modal ekonomi yang dimiliki secara cekap dan produktif (Sims, 2006).

\section{Metodologi, Pembentukan Indeks dan Spesifikasi Model}

\section{Persampelan dan Pengumpulan Data}

Data yang dikumpulkan dalam kajian ini adalah berdasarkan kerja lapangan yang dijalankan pada 2007/2008 di seluruh Semenanjung 
Malaysia menggunakan set soal selidik. Dalam kajian ini, metod persampelan berstrata telah digunakan untuk mendapatkan saiz sampel mengikut wilayah, zon, negeri, lokasi dan etnik. Populasi isi rumah diperoleh daripada Banci Penduduk dan Perumahan Malaysia (Malaysia, 2001) dan komposisi populasi pula berasaskan Rancangan Malaysia Ke-Sembilan (Malaysia, 2009). Sebanyak 5,000 sampel isi rumah telah ditetapkan pada awal kajian dan hanya 4,003 isi rumah yang berjaya di soal selidik.

\section{Pembentukan dan Pengukuran Indeks Modal Sosial dan Modal Manusia}

Indeks modal sosial dan modal insan bagi kajian ini dibentuk berasaskan pendekatan Indeks Pembangunan Manusia (Human Development Index - HDI) yang diperkenalkan oleh UNDP (2006). Komponen-komponen yang digunakan untuk membentuk Indeks Modal Sosial dan Indeks Modal Insan ditunjukkan dalam Jadual 2 dan 3. Pemberian nilai/pemberat untuk setiap komponen modal sosial dan modal manusia yang ditetapkan dalam kajian ini adalah berdasarkan pandangan pengkaji terhadap kepentingan dan sumbangan setiap komponen terhadap pembentukan modal sosial dan modal manusia seseorang individu. Bagi Indeks Modal Sosial, komponen norma hidup diberi nilai yang lebih besar berbanding komponen modal sosial yang lain kerana nilai hidup baik yang menjadi amalan akan berupaya memberi impak positif yang besar kepada modal sosial keseluruhan bagi individu. Indikator dalam komponen ini iaitu pegangan/prinsip hidup diberikan nilai wajaran sebanyak 0.6 dan indikator hubungan kemasyarakatan diberikan nilai wajaran 0.4. Komponen kepercayaan dan jaringan pula diberikan nilai wajaran sebanyak 0.3 dan 0.2 (lihat Jadual 2).

Jadual 2

Pengukuran Indeks Modal Sosial

\begin{tabular}{|c|c|}
\hline Komponen $(j)$ & Indikator $(k)$ \\
\hline $\begin{array}{l}\text { Jaringan } \\
(\text { Wajaran = 0.2) }\end{array}$ & $\begin{array}{l}\text { a. Jaringan Organisasi }(\text { Wajaran }=0.3) \\
\text { b. Jaringan Kekeluargaan }(\text { Wajaran }=0.5) \\
\text { c. Jaringan Rakan \& Jiran }(\text { Wajaran }=0.2)\end{array}$ \\
\hline $\begin{array}{l}\text { Kepercayaan } \\
(\text { Wajaran }=0.3)\end{array}$ & $\begin{array}{l}\text { a. Aspek Kewangan }(\text { Wajaran }=0.7) \\
\text { b. } \quad \text { Bukan Kewangan }(\text { Wajaran }=0.3)\end{array}$ \\
\hline
\end{tabular}

(sambungan) 


\begin{tabular}{ll}
\hline Komponen $(j)$ & Indikator $(k)$ \\
\hline Norma Hidup & a. Pegangan / Prinsip Hidup (Wajaran = 0.6) \\
$($ Wajaran $=0.5)$ & b. Hubungan Kemasyarakatan (Wajaran =0.4) \\
Indeks Modal Sosial & \\
$($ Pemberat $=1)$ & \\
\hline
\end{tabular}

Komponen pendidikan diberikan nilai wajaran yang paling besar (0.6) dalam pembentukan indeks modal manusia. Indikator dalam komponen ini, iaitu jumlah tahun persekolahan diberi nilai wajaran sebanyak 0.8. Sementara itu, dua indikator lain dalam komponen yang sama iaitu tempat pengajian dan aliran persekolahan masingmasing diberi nilai wajaran 0.1. Komponen pendidikan diberi nilai yang paling besar berbanding komponen lain berdasarkan impak besar pendidikan ke atas kedudukan modal manusia individu dan keupayaannya membantu meningkat dan mengekalkan kualiti hidup yang lebih baik. Komponen latihan, pengalaman kerja dan kesihatan pula masing-masing diberikan nilai wajaran sebanyak 0.2 dan 0.1 (lihat Jadual 3).

Jadual 3

Pengukuran Indeks Modal Manusia

\begin{tabular}{|c|c|}
\hline Komponen $(j)$ & Indikator $(k)$ \\
\hline $\begin{array}{l}\text { Pendidikan } \\
(\text { Wajaran = 0.6) }\end{array}$ & $\begin{array}{ll}\text { a. } & \text { Tahun Bersekolah }(\text { Wajaran }=0.8) \\
\text { b. } & \text { Tempat Pengajian }(\text { Wajaran }=0.1) \\
\text { c. } & \text { Aliran Pendidikan }(\text { Wajaran }=0.1)\end{array}$ \\
\hline $\begin{array}{l}\text { Latihan } \\
(\text { Wajaran = 0.2) }\end{array}$ & $\begin{array}{l}\text { a. Tempoh Latihan }(\text { Wajaran }=0.5) \\
\text { b. Jenis Latihan }(\text { Wajaran }=0.25) \\
\text { c. Lokasi dan Bentuk Latihan }(\text { Wajaran }=0.25)\end{array}$ \\
\hline $\begin{array}{l}\text { Pengalaman (Wajaran } \\
=0.1)\end{array}$ & a. Tempoh Pengalaman Kerja $($ Wajaran $=1)$ \\
\hline $\begin{array}{l}\text { Kesihatan } \\
(\text { Wajaran = 0.1) }\end{array}$ & $\begin{array}{l}\text { a. Persepsi }(\text { Wajaran }=0.1) \\
\text { b. Penyakit Kronik }(\text { Wajaran }=0.25) \\
\text { c. } \text { Cuti Sakit }(\text { Wajaran }=0.25) \\
\text { d. Jumlah Lawatan ke Hospital atau Klinik } \\
\text { (Wajaran }=0.25) \\
\text { e. } \text { Gaya hidup (Persepsi) }(\text { Wajaran }=0.15)\end{array}$ \\
\hline $\begin{array}{l}\text { Indeks Modal Manusia } \\
(\text { Pemberat = 1) }\end{array}$ & \\
\hline
\end{tabular}


Pengiraan indeks modal sosial dan modal manusia telah disesuaikan dari Indeks Pembangunan Manusia (Human Development Index - HDI) yang diperkenalkan oleh UNDP (2006). Pengiraan indeks ini boleh dilihat seperti dibawah.

Langkah pertama : Pengiraan indeks agregat untuk setiap komponen

Pada langkah pertama ini, jumlah skor untuk setiap indikator yang digunakan akan dijumlahkan dan digunakan bagi menggambarkan dimensi modal manusia. Persamaan umum seperti di bawah boleh digunakan untuk mendapatkan nilai skor untuk setiap komponen berkenaan.

$I_{j}^{i}=\frac{1}{n} \sum_{k=1}^{n} \tilde{X}_{k}^{i}$

Di mana, $I_{j}^{i}$ merupakan indeks agregat untuk komponen $j$ dan $n$ adalah jumlah indikator dalam komponen j. Manakala $\widetilde{X}_{k}^{i}$ merupakan penormalan jumlah nilai skor individu $i$ bagi setiap indikator $k$ yang mana ia mampunyai nilai antara 0 dan $1 . \widetilde{X}_{k}^{i}$ boleh dikira mengikut formula berikut:

$\widetilde{X}_{k}^{i}=\frac{\text { actual value }- \text { min imum value }}{\text { maximum value }- \text { min imum value }}$

Nilai skor yang telah dinormalkan ini boleh membentuk suatu indeks umum sebagai ukuran kepada dimensi modal manusia seperti yang ditunjukkan pada Jadual Pengukuran Indeks di atas.

Langkah kedua : Pengiraan indeks untuk setiap dimensi

Langkah kedua pula adalah mengira indeks untuk dimensi setiap komponen menggunakan persamaan berikut.

$Z_{y}^{i}=\sum_{j=1}^{m} w_{j} I_{j}^{i}$

Dengan $Z_{y}^{i}$ adalah indeks agregat untuk dimensi $y, m$ merupakan bilangan komponen dalam $y$ dan $w_{j}$ adalah nilai wajaran yang diberikan terhadap setiap indeks komponen berdasarkan

262 IJMS 17 (2), 253-274 (2010) 
kepentingan. Manakala $I_{j}^{i}$ merupakan nilai indeks komponen ke $j$ yang diperolehi melalui persamaan (1).

Langkah ketiga : Pengiraan Indeks Modal Manusia

Langkah terakhir pembentukan indeks modal manusia adalah dengan menjumlahkan indeks-indeks mengikut dimensi yang setiap satunya diperolehi dari persamaan (3). $Z_{y}^{i}$ mewakili indeks bagi dimensi mengikut komponen manakala $w_{y}$ adalah nilai wajaran yang diberikan bagi indeks dimensi berkenaan mengikut kepentingan masing-masing.

$H C I^{i}=\sum_{y} w_{y} Z_{y}^{i}$

Nilai $H C I^{i}$ yang diperoleh akan berada antara nilai 0 hingga 1. Nilai yang menghampiri 1 menggambarkan kedudukan modal sosial dan modal manusia yang tinggi dan sebaliknya jika menghampiri 0 menunjukkan kedudukan modal sosial dan modal manusia yang lemah. Penarafan nilai skala indeks pula boleh dilihat pada Jadual 4 bagi menafsir kedudukan indeks modal sosial dan modal manusia yang dihasilkan.

Jadual 4

Penarafan Nilai Skala Indeks Modal Sosial dan Modal Manusia

\begin{tabular}{ll}
\hline Nilai Skala Indeks & Tahap Modal Manusia \\
\hline Kurang daripada 0.2000 & Amat Lemah \\
0.2001 to 0.4000 & Lemah \\
0.4000 to 0.6000 & Sederhana \\
0.6001 to 0.8000 & Tinggi \\
Lebih daripada 0.8000 & Sangat Tinggi \\
\hline
\end{tabular}

\section{Spesifikasi Model}

Terdapat dua kaedah analisis data yang digunakan dalam makalah ini. Pertama, analisis secara penjadualan frekuensi, penjadualan silang dan ujian ANOVA F-test untuk menguji perbezaan min pemboleh 
ubah. Kedua, bagi melihat pengaruh indeks modal sosial terhadap agihan pendapatan yang diterima oleh isi rumah, kaedah regresi linear digunakan. Pengaruh pemboleh ubah bebas (modal sosial) dan pemboleh ubah bebas lain (seperti pendidikan, latihan, kesihatan dan demografi) terhadap pemboleh ubah bersandar (agihan pendapatan isi rumah) diuji dengan menggunakan model-model berikut.

$$
\begin{aligned}
& I R_{i}=\beta_{0}+\beta_{1} Y E d u+\beta_{2} D T+\beta_{3} \operatorname{Exp}+\beta_{4} H L s+ \\
& \beta_{5} D G+\beta_{6} D D L+\beta_{7} D U+\beta_{8} S C I+\mu
\end{aligned}
$$

dengan,

IR = Peratus Nisbah Pendapatan Isi Rumah Bekerja* (pemboleh ubah bersandar sebagai proksi kepada agihan pendapatan)

YEdu = Purata Tahun Bersekolah Isi Rumah

DT = Dami Menghadiri Latihan Bagi Ketua Isi Rumah, (1 = ada latihan; 0 = tiada latihan)

$\operatorname{Exp}=$ Purata Pengalaman Bekerja Isi Rumah (jumlah tahun)

HLs = Purata Gaya Hidup Sihat Isi Rumah

DG $=$ Dami Gender Ketua Isi Rumah $(1=$ Lelaki $; 0=$ Wanita $)$

DDL = Dami wilayah $(1=$ maju; $0=$ kurang maju $)$

DU $\quad=$ Dami Lokasi $(1=$ bandar; $0=$ luar bandar $)$

$\mathrm{SCI}=$ Indeks Modal Sosial Ketua Isi Rumah

$\mu \quad=$ ralat

$$
I R_{i}=\beta_{0}+\beta_{1} H C I+\beta_{2} S C I+\beta_{3} D G+\beta_{4} D D L+\beta_{5} D U+\mu
$$

$I R_{i}=\beta_{0}+\beta_{1} H C I+\beta_{2} S C I+\mu$

dengan,

$\mathrm{HCI}=$ Purata Indeks Modal Manusia Isi Rumah

Nota. * Walaupun pekali Gini sering digunakan oleh para pengkaji untuk mengukur ketidakseimbangan pendapatan, terdapat beberapa pengukuran lain yang boleh digunakan bagi tujuan yang sama. Salah satu daripadanya ialah nisbah pendapatan (Jordahl, H. 2009). Untuk kajian ini, peratus nisbah pendapatan isi rumah diperoleh daripada membahagikan jumlah pendapatan setiap isi rumah yang bekerja dengan jumlah keseluruhan pendapatan isi rumah dan didarabkan dengan seratus.

264 IJMS 17 (2), 253-274 (2010) 


\section{Penemuan Kajian}

\section{Profil isi rumah}

Jadual 5 menunjukkan profil isi rumah dalam kajian ini mengikut gender dan kaum. Daripada sebanyak 4003 ketua isi rumah yang diliputi dalam kajian ini, 94.3\% adalah terdiri daripada lelaki dan hanya $5.7 \%$ diwakili oleh perempuan. Majoriti ketua isi rumah dalam kajian ini adalah berbangsa Melayu (70.4\%), diikuti oleh Cina (22.8\%) dan India (6.8\%). Sebahagian besar daripada ketua dan ahli isi rumah untuk kajian ini tinggal dan bekerja di kawasan bandar (67.9\%). Jumlah ketua isi rumah yang tinggal dan bekerja di kawasan luar bandar pula hanya sebanyak 32.1\%. Dari segi kaum, analisis kajian menunjukkan bilangan dan peratusan ketua isi rumah Melayu yang tinggal dan bekerja di kawasan bandar dan luar bandar adalah lebih tinggi berbanding kaum-kaum lain (lihat Jadual 6).

Jadual 5

Taburan Isi Rumah Mengikut Gender dan Kaum

\begin{tabular}{lrrrrrr}
\hline & \multicolumn{3}{c}{ Ketua Isi Rumah } & \multicolumn{2}{c}{ Jumlah } \\
\cline { 2 - 5 } $\begin{array}{l}\text { Kumpulan } \\
\text { Etnik }\end{array}$ & \multicolumn{2}{c}{ Lelaki } & \multicolumn{2}{c}{ Perempuan } & & \\
\cline { 2 - 6 } & Frekuensi & $\begin{array}{c}\text { Peratus } \\
(\%)\end{array}$ & Frekuensi & $\begin{array}{c}\text { Peratus } \\
(\%)\end{array}$ & Frekuensi & $\begin{array}{c}\text { Peratus } \\
(\%)\end{array}$ \\
\hline Melayu & 2644 & 70.0 & 175 & 77.1 & 2819 & 70.4 \\
Cina & 872 & 23.1 & 40 & 17.6 & 912 & 22.8 \\
India & 260 & 6.9 & 12 & 5.3 & 272 & 6.8 \\
Jumlah & 3776 & 100.0 & 227 & 100.0 & 4003 & 100.0 \\
\hline
\end{tabular}

Nota. $\mathrm{N}=4003$

Sumber. Kerja Lapangan 2007/2008

Berdasarkan bidang pekerjaan, sebahagian besar pekerja dalam sampel isi rumah bekerja dalam sektor perkhidmatan berbanding sektor pekerjaan lain. Jadual 7 menunjukkan $72.1 \%$ isi rumah bekerja di sektor perkhidmatan. Berdasarkan kawasan, sebanyak 78.0\% dan $59.5 \%$ isi rumah bekerja di kawasan bandar dan luar bandar terlibat dalam sektor ini. Pembuatan merupakan sektor pekerjaan yang mencatatkan penyertaan kedua teramai dalam kalangan isi rumah bekerja iaitu sebanyak $14.7 \%$. Sektor pertanian pula ditangga ketiga, mencatatkan peratus penyertaan isi rumah sebanyak 8.2\%. Dari segi 
lokasi, didapati bilangan dan peratusan isi rumah yang menyertai sektor pertanian adalah lebih tinggi di kawasan luar bandar iaitu $21.2 \%$ berbanding $2.1 \%$ di bandar.

Jadual 6

Taburan Isi Rumah Bekerja Mengikut Kahum dan Lokasi Kediaman

\begin{tabular}{lcccccc}
\hline \multirow{2}{*}{$\begin{array}{c}\text { Kumpulan } \\
\text { Etnik }\end{array}$} & \multicolumn{3}{c}{ Bokasi Kediaman } & \multicolumn{3}{c}{ Jumlah } \\
\cline { 2 - 6 } & Frekuensi & $\begin{array}{c}\text { Peratus } \\
(\%)\end{array}$ & Frekuensi & $\begin{array}{c}\text { Peratus } \\
(\%)\end{array}$ & Frekuensi & $\begin{array}{c}\text { Peratus } \\
(\%)\end{array}$ \\
\cline { 2 - 6 } Melayu & 3388 & 71.0 & 1745 & 77.3 & 5133 & 73.0 \\
Cina & 1060 & 22.2 & 386 & 17.1 & 1446 & 20.6 \\
India & 323 & 6.8 & 125 & 5.5 & 448 & 6.4 \\
Jumlah & 4771 & 100.0 & 2256 & 100.0 & 7027 & 100.0 \\
\hline
\end{tabular}

Nota. $\mathrm{N}=7032$ isi rumah bekerja (Tidak Lengkap = 5 isi rumah bekerja) Isi rumah bekerja termasuk pekerja sepenuh masa, pekerja separuh masa \& bekerja sendiri

Sumber. Kerja Lapangan 2007/2008

Jadual 7

Taburan Isi Rumah Bekerja Mengikut Sektor

\begin{tabular}{lrrrrrr}
\hline & \multicolumn{3}{c}{ Lokasi Kediaman } & \multicolumn{2}{c}{ Jumlah } \\
\cline { 2 - 5 } Sektor & \multicolumn{2}{c}{ Bandar } & \multicolumn{2}{c}{ Luar Bandar } & & \\
\cline { 2 - 5 } & Frekuensi & $\begin{array}{c}\text { Peratus } \\
(\%)\end{array}$ & Frekuensi & $\begin{array}{c}\text { Peratus } \\
(\%)\end{array}$ & Frekuensi & $\begin{array}{c}\text { Peratus } \\
(\%)\end{array}$ \\
\hline Perkhidmatan & 3678 & 78.0 & 1330 & 59.5 & 5008 & 72.1 \\
Pembuatan & 723 & 15.3 & 297 & 13.3 & 1020 & 14.7 \\
Pertanian & 99 & 2.1 & 474 & 21.2 & 573 & 8.2 \\
Perlombongan & 9 & 0.2 & 2 & 0.1 & 11 & 0.2 \\
Pembinaan & 206 & 4.4 & 131 & 5.9 & 337 & 4.8 \\
Jumlah & 4715 & 100.0 & 2234 & 100.0 & 6949 & 100.0 \\
\hline
\end{tabular}

Nota $. \mathrm{N}=7032$ isi rumah bekerja (Tidak Lengkap $=83$ isi rumah bekerja) Isi rumah bekerja termasuk pekerja sepenuh masa, pekerja separuh masa \& bekerja sendiri

Sumber. Kerja Lapangan 2007/2008

266 IJMS 17 (2), 253-274 (2010) 
Berdasarkan Jadual 8, sebanyak 28.3\% isi rumah bekerja dalam kajian ini didapati lebih tertumpu kepada kategori pekerja perkhidmatan dan jualan berbanding kategori pekerjaan lain. Berdasarkan lokasi, analisis menunjukkan sebanyak masing-masing $28.8 \%$ dan $27.3 \%$ isi rumah dikawasan bandar dan luar bandar terlibat dalam kategori pekerjaan ini. Kategori profesional mencatatkan penyertaan kedua teramai isi rumah iaitu sebanyak $16.9 \%$ dengan peratus isi rumah berdasarkan kawasan yang terlibat dengan kategori ini ialah sebanyak 20.1\% (bandar) dan 10.2\% (luar bandar).

Jadual 8

Taburan Isi Rumah Bekerja Mengikut Kategori Pekerjaan

\begin{tabular}{|c|c|c|c|c|c|c|}
\hline \multirow{3}{*}{$\begin{array}{l}\text { Kategori } \\
\text { Pekerjaan }\end{array}$} & \multicolumn{4}{|c|}{ Lokasi Kediaman } & \multirow{2}{*}{\multicolumn{2}{|c|}{ Jumlah }} \\
\hline & \multicolumn{2}{|c|}{ Bandar } & \multicolumn{2}{|c|}{ Luar Bandar } & & \\
\hline & Frekuensi & $\begin{array}{l}\text { Peratus } \\
(\%)\end{array}$ & Frekuensi & $\begin{array}{l}\text { Peratus } \\
(\%)\end{array}$ & Frekuensi & $\begin{array}{l}\text { Peratus } \\
(\%)\end{array}$ \\
\hline $\begin{array}{l}\text { Pegawai Kanan } \\
\text { dan Pengurus }\end{array}$ & 357 & 7.7 & 78 & 3.6 & 435 & 6.4 \\
\hline Profesional & 935 & 20.1 & 224 & 10.2 & 1159 & 16.9 \\
\hline $\begin{array}{l}\text { Juru teknik dan } \\
\text { Profesional } \\
\text { Bersekutu }\end{array}$ & 406 & 8.7 & 149 & 6.8 & 555 & 8.1 \\
\hline $\begin{array}{l}\text { Pekerja } \\
\text { Perkeranian }\end{array}$ & 574 & 12.3 & 166 & 7.6 & 740 & 10.8 \\
\hline $\begin{array}{l}\text { Pekerja } \\
\text { Perkhidmatan } \\
\text { dan Jualan }\end{array}$ & 1342 & 28.8 & 597 & 27.3 & 1939 & 28.3 \\
\hline $\begin{array}{l}\text { Pekerja } \\
\text { Pertanian dan } \\
\text { Perikanan }\end{array}$ & 82 & 1.8 & 422 & 19.3 & 504 & 7.4 \\
\hline $\begin{array}{l}\text { Pekerja Kraf dan } \\
\text { Perdagangan } \\
\text { Berkaitan }\end{array}$ & 42 & 0.9 & 31 & 1.4 & 73 & 1.1 \\
\hline $\begin{array}{l}\text { Operator Kilang, } \\
\text { Mesin dan } \\
\text { Pemasangan }\end{array}$ & 480 & 10.3 & 215 & 9.8 & 695 & 10.1 \\
\hline Pekerjaan Asas & 441 & 9.5 & 307 & 14.0 & 748 & 10.9 \\
\hline Jumlah & 4659 & 100.0 & 2189 & 100.0 & 6848 & 100.0 \\
\hline
\end{tabular}

Nota . $\mathrm{N}=7032$ isi rumah bekerja (Tidak Lengkap = 184 isi rumah bekerja) Isi rumah bekerja termasuk pekerja sepenuh masa, pekerja separuh masa \& bekerja sendiri

Sumber. Kerja Lapangan 2007/2008

IJMS 17 (2), 253-274 (2010) 
Analisis kajian ini menunjukkan indeks modal sosial bagi isi rumah yang tinggal di wilayah kurang membangun adalah lebih tinggi berbanding wilayah membangun. Berdasarkan Jadual 9, analisis terhadap nilai purata indeks modal sosial berdasarkan faktor gender, etnik, lokasi dan sektor pekerjaan menunjukkan terdapat perbezaan yang signifikan antara kedua wilayah. Nilai indeks modal sosial bagi wilayah kurang membangun yang secara umumnya lebih tinggi berbanding di wilayah membangun menggambarkan amalan/norma hidup baik dan hubungan kemasyarakatan yang masih kuat dipegang dan diamalkan dalam kalangan isi rumah di wilayah tersebut.

Jadual 9

Purata Indeks Modal Sosial Isi rumah Mengikut Wilayah, Lokasi dan Sektor Pekerjaan Bagi Ketua Isi Rumah Lelaki dan Wanita

\begin{tabular}{lcccc}
\hline \multirow{2}{*}{ Faktor } & \multicolumn{4}{c}{ Wilayah } \\
\cline { 2 - 5 } & \multicolumn{2}{c}{ Membangun } & Kurang Membangun \\
\cline { 2 - 5 } & Bilangan (n) & $\begin{array}{c}\text { Purata } \\
\text { Indeks }\end{array}$ & Bilangan (n) & $\begin{array}{c}\text { Purata } \\
\text { Indeks }\end{array}$ \\
\cline { 2 - 5 } Gender & & & & \\
Lelaki & 2832 & 0.5902 & 944 & 0.6106 \\
Perempuan & 164 & 0.5559 & 63 & 0.5829 \\
\hline Jumlah & 2996 & 0.588302 & 1007 & 0.6089 \\
\hline Kumpulan Etnik & & & & \\
Melayu & 2115 & 0.5938 & 704 & 0.6134 \\
Cina & 679 & 0.5719 & 233 & 0.5982 \\
India & 202 & 0.5857 & 70 & 0.5990 \\
\hline Jumlah & 2996 & 0.5883 & 1007 & 0.6089 \\
\hline Lokasi & & & & \\
Luar Bandar & 2327 & 0.5863 & 422 & 0.6305 \\
Bandar & 669 & 0.5952 & 585 & 0.5933 \\
\hline Jumlah & 2996 & 0.5883 & 1007 & 0.6089 \\
\hline Sektor Pekerjaan & & & & \\
Perkhidmatan & 1947 & 0.5982 & 538 & 0.6097 \\
\hline & & & & (sambungan)
\end{tabular}




\begin{tabular}{lcccc}
\hline \multirow{2}{*}{ Faktor } & \multicolumn{4}{c}{ Wilayah } \\
\cline { 2 - 5 } & Bilangan (n) & $\begin{array}{l}\text { Purata } \\
\text { Indeks }\end{array}$ & Bilangan (n) & $\begin{array}{c}\text { Purata } \\
\text { Indeks }\end{array}$ \\
\cline { 2 - 5 } & 421 & 0.5642 & 88 & 0.6757 \\
Pembuatan & 226 & 0.6153 & 222 & 0.5941 \\
Pertanian & 4 & 0.6576 & 5 & 0.6046 \\
Perlombongan & 170 & 0.5938 & 76 & 0.6239 \\
Pembinaan & 2768 & 0.5942 & 929 & 0.6134 \\
\hline Jumlah & 2996 & 0.5883 & 1007 & 0.6089 \\
\hline Jumlah Keseluruhan & & & & \\
\hline
\end{tabular}

Nota. $\mathrm{N}=4003$

(Formula Pengiraan Indeks Modal Sosial: $S C I_{i}^{c}=\sum_{y=1}^{n} w z_{y}^{i}$
Sumber. Kerja Lapangan 2007/2008

\section{Keputusan Penganggaran}

Keputusan penganggaran model regresi bagi menentukan pengaruh modal sosial terhadap agihan pendapatan isi rumah ditunjukkan dalam Jadual 10. Secara keseluruhannya, hasil penganggaran untuk model pertama mendapati hampir kesemua pemboleh ubah bebas mempunyai pengaruh yang signifikan terhadap pemboleh ubah bersandar (peratus jumlah pendapatan isi rumah bekerja). Pengaruh pendidikan, latihan, pengalaman bekerja dan kesihatan didapati signifikan pada aras keertian $99 \%$. Peningkatan dalam tahap pendidikan dan latihan yang diterima, pengalaman bekerja dan pengamalan cara hidup sihat adalah signifikan dalam meningkatkan peratus jumlah pendapatan isi rumah dan ini setrusnya akan membantu mengurangkan ketidakseimbangan agihan pendapatan. Analisis kajian juga menunjukkan wilayah dan lokasi tempat tinggal dan bekerja isi rumah adalah signifikan dalam mempengaruhi peratus pendapatan isi rumah. Isi rumah yang tinggal dan bekerja di kawasan bandar di wilayah membangun didapati mempunyai jumlah pendapatan yang lebih seimbang berbanding isi rumah di kawasan luar bandar di wilayah kurang membangun. Namun demikian, analisis ini mendapati modal sosial dalam bentuk indeks adalah tidak signifikan dari segi pengaruhnya terhadap agihan pendapatan isi rumah. 


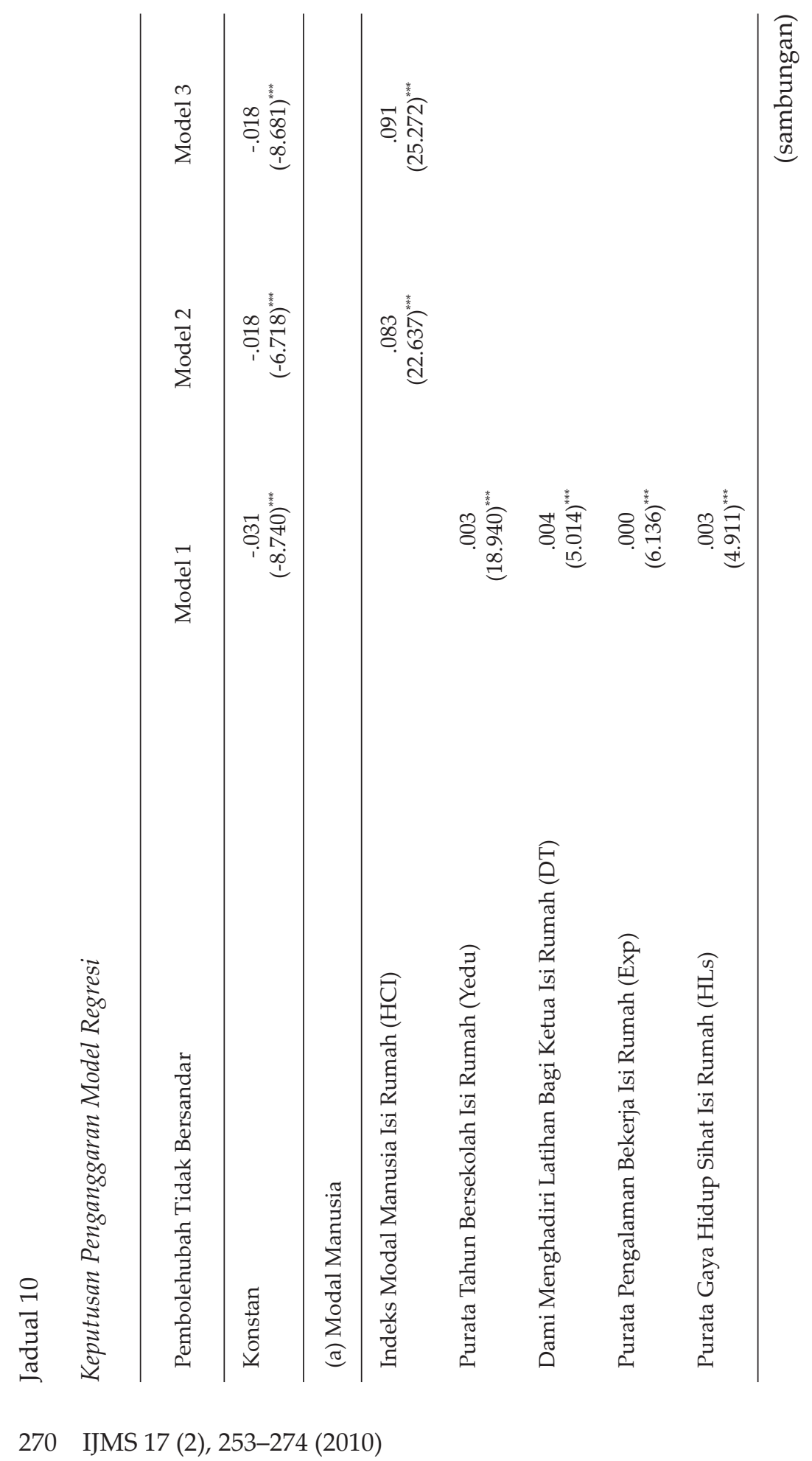




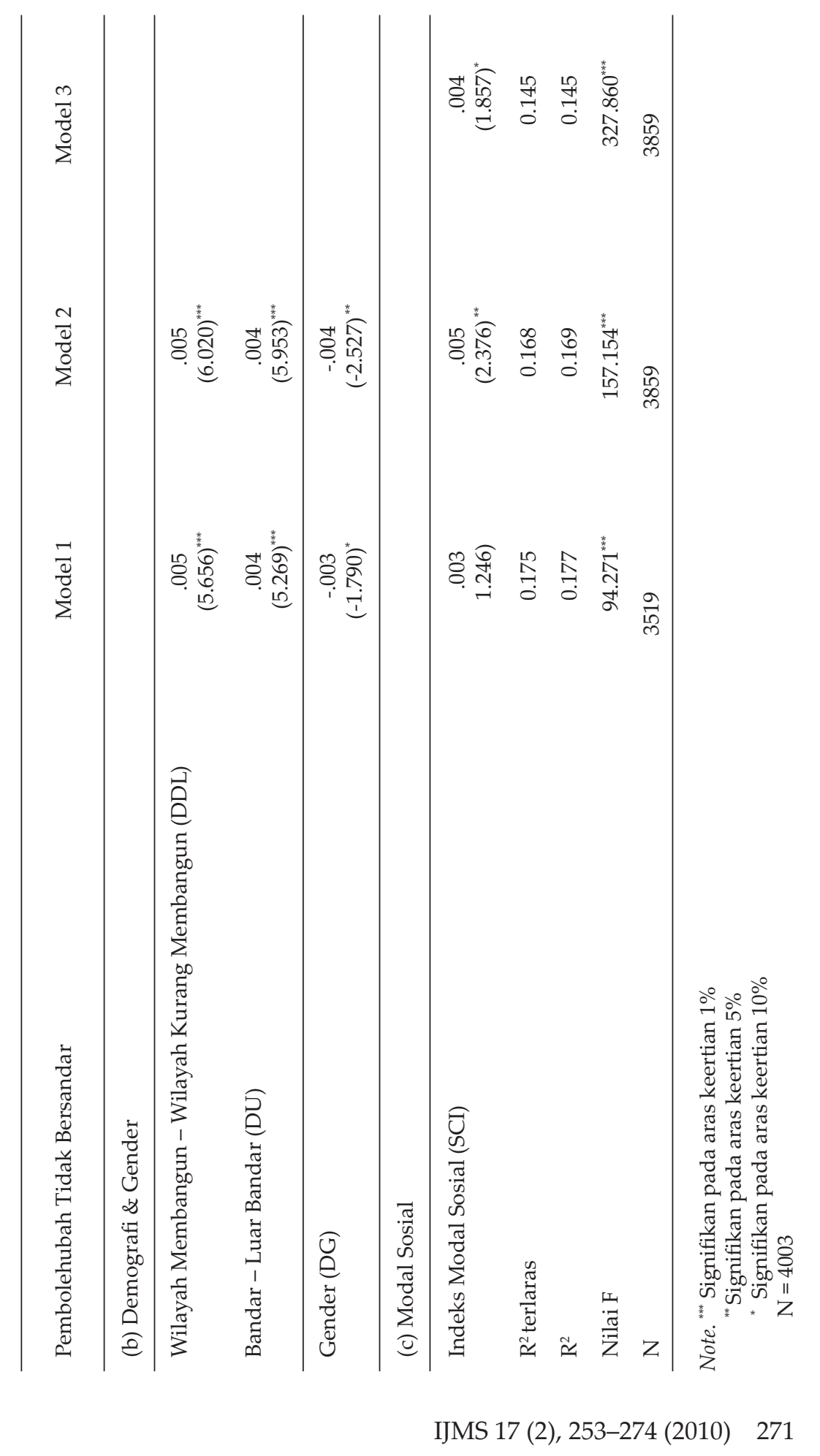


Keputusan penganggaran untuk model regresi kedua dan ketiga juga mendapati modal manusia (dalam bentuk indeks) kekal memberikan pengaruh yang signifikan terhadap peratus agihan pendapatan yang diterima oleh isi rumah. Pengaruh modal sosial (dalam bentuk indeks) didapati signifikan terhadap agihan pendapatan isi rumah bagi model kedua dan ketiga (lihat Jadual 9). Analisis modal sosial dalam bentuk indeks dalam model kedua dan ketiga menunjukkan bahawa 1 mata kenaikan dalam indeks modal sosial akan meningkatkan sebanyak 0.005 dan $0.004 \%$ titik peratusan pendapatan isi rumah. Keputusan ini secara tidak langsung dapat memberi gambaran mengenai kepentingan elemen-elemen modal sosial, iaitu rangkaian (termasuk persatuan), kepercayaan dan norma hidup dalam mempengaruhi peratus dan agihan pendapatan isi rumah.

\section{Rumusan dan Implikasi Dasar}

Hasilkajianinimenyokong penemuankajian-kajianlepassepertikajian Maluccio et al. (1999) dan Grootaert (1999) yang mendapati modal sosial mempunyai pengaruh yang positif terhadap agihan pendapatan walaupun lebih kecil berbanding pengaruh faktor lain seperti modal manusia. Walaupun diakui modal manusia adalah merupakan antara faktor penting dalam menentukan jumlah pendapatan dan agihan pendapatan di antara penduduk, namun analisis ekonomi terhadap agihan pendapatan kini tidak boleh mengabaikan kepentingan faktor modal sosial. Kajian ekonomi terhadap modal sosial yang mula berkembang pesat sejak tahun 1980-an hingga kini jelas menunjukkan bahawa elemen perhubungan sosial antara individu, masyarakat dan firma yang dibentuk berasaskan kepercayaaan dan norma hidup baik yang menjadi pegangan dan amalan mampu menjana impak positif terutamanya ke atas peningkatan produktiviti individu dan firma.

Keputusan penganggaran model regresi kedua dan ketiga jelas memperlihatkan pengaruh modal sosial (dalam bentuk indeks) terhadap agihan pendapatan. Keputusan ini secara tidak langsung dapat memberi gambaran mengenai kepentingan elemen-elemen dalam modal sosial iaitu perhubungan, kepercayaan dan norma hidup baik untuk diamal dan dipertahankan oleh setiap anggota masyarakat. Selain meneruskan fokus terhadap pelaburan dalam modal manusia, negara kini perlu meningkatkan usaha untuk membentuk modal manusia yang bukan sahaja berpendidikan dan berkemahiran tetapi dilengkapi oleh sahsiah diri yang tinggi. Sejajar dengan matlamat kerajaan yang telah digariskan dalam RMke-9 untuk 
membangunkan modal insan (modal manusia yang berpendidikan, berkemahiran dan mempunyai sahsiah diri yang tinggi), modal sosial kini semakin diterima sebagai modal keempat dan pelengkap kepada semua modal yang penting kepada pertumbuhan ekonomi.

Penemuan kajian ini perlu dijadikan panduan dan asas untuk kajian yang lebih terperinci dilakukan khususnya dalam memperincikan konsep dan kaedah pengukuran modal sosial. Walaupun pengaruh modal sosial adalah lebih kecil berbanding pengaruh modal manusia namun dapatan kajian ini adalah penting dalam menggambarkan kepentingan dan pengaruh modal yang bersifat intangible ini terhadap peratus dan agihan pendapatan isi rumah di Malaysia.

\section{Rujukan}

Becker, Gary S., (1964). Human capital. New York: NBER.

Bigsten, A., Collier, P., Dercon, S., Fafchamps, M., Gauthier, B., Gunning, J. W., Isaksson, A., Oduro, A., Oostendorp, R., Patillo, C., Soderborn, M., Teal, F., \& Zeufack, A. (2000). Contract flexibility and dispute resolution in African manufacturing. Journal of Development Studies, 36, 1-37.

Coleman, J. S. (1988). Social capital in the creation of human capital. American Journal of Sociology, 94 (supplement), S95-S120.

Coleman,J. S. (1990). Foundations of social theory. Cambridge: Harvard University Press.

Fafchamps, M., \& Minten, B. (2001). Property rights in a flea market economy. Economic Development and Cultural Change, 49, 229268.

Fafchamps, M., \& Minten, B. (2002). Returns to social network capital among traders. Oxford Economic Papers, 54, 173-206.

Fukuyama, F. (1997). Social capital, tanner lecture on human value.

Grootaert, C. (1999). Social capital, household welfare, and poverty in Indonesia. World Bank Policy Research Working Paper. No. WPS2148.

Grootaert, C., \& Narayan, D. (2001). Local institutions, poverty, and household welfare in Bolivia.World Bank Policy Research Working Paper. No.2644.

Jordahl, H. (2009). Economic inequality. InGert Tinggaard Svendsen \& Gunnar Lind Haase Svendsen (Eds.), Handbook of social capital. The troika of sociology, Political Science and Economics. 2009. Edward Elgar Publishing. UK. 
Knack. S.(2002). Social capital, growth, and poverty: A survey of cross-country evidence. In Grootaert. C. et al (Eds.), The role of social capital in development. An empirical assessment. Cambridge University Press.

Knowles, S. (2005). The future of social capital in development economics research. Paper prepared for the WIDER Jubilee Conference (Thinking ahead: The future of development economics). Helsinki, 17-18 June 2005.

Malaysia. (2006). Rancangan Malaysia Kesembilan, 2006-2010. Kuala Lumpur: Percetakan Nasional.

Malaysia. (2008). Kajian Separuh Penggal Rancangan Malaysia Kesembilan. Kuala Lumpur: Percetakan Nasional.

Maluccio, J., Haddad, L., \& May, J. (1999). Social capital and income generation in South African, 1993-98, A paper presented at IDSIFPRI workshop on "Economic Mobility and Poverty Dynamics in Developing Countries", April 1999.

Piazza-Georgi, B. (2002). The role of human and social capital in growth: Extending our understanding. Cambridge Journal of Economics, 461-479.

Putnam, R. D. (1993). Making democracy work: Civic institutions in modern Italy. Princeton, NJ: Princeton University Press.

Robinson, L. J., \& Siles, M.E. (1999). Social capital and household income distributions in the United States: 1980, 1990. Journal of Socio-Economics, 28, 43-93.

Sims, E. (2006). Social capital in firms, alliances \& clusters: Why it is important for productivity \& competitiveness: And how to build it, in Wee-Liang, T. (Eds.), Social capital in Asia: An exploratory study. Asian Productivity Organization (APO).

Schultz, T.W. (n.d). Investment in human capital. American Economic Review, 51(1), 1-17.

Uchimura, H. (2005). Influence of social institutions on inequality in China. Institute of Development Economics, discussion paper no.26. Retreived at http://www.ide.go.jp

UNDP. (2006). Human development report 2006. New York: Palgrave Macmillan.

Woolcock, M., \& Narayan, D. (2000). Social capital: Implications for development theory, research, and policy. The World Bank Research Observer, 15, 225-249.

Woolcock, M. (1998). Social capital and economic development: Towards a theoretical synthesis and policy framework. Theory and Society, 2, 151-208. 